\title{
Implementation of CDIO Approach in training engineering specialists for the benefit of sustainable development
}

\author{
Yury Daneykin ${ }^{1, a}$, Natalia Daneikina ${ }^{1}$ and Viktoria Sadchenko ${ }^{1}$ \\ ${ }^{1}$ National Research Tomsk Polytechnic University, 634050 Tomsk, Russia
}

\begin{abstract}
Due to the competition and changing needs of the world, universities strive to analyze these needs to timely offer necessary educational programs. One of the newest trends in engineering education is sustainable development. To support the concept and implement it into life it is necessary to train specialists able to promote sustainable development that inevitably leads to the necessity to develop educational programs embracing newest approaches considering up-to-date conditions and requirements. There are many efforts globally to develop educational programs for sustainable development. One of the common problems for Universities around the world is the virtual absence of comprehensive educational programs preparing specialists for sustainable development at all three levels of educational process: Bachelor's, Master's and $\mathrm{PhD}$ levels. Authors analyze the content of existing educational programs for sustainable development and suggest using Conceive, Design, Implement and Operate (CDIO) Approach, Standards and Syllabus that might be successfully applied for the development of up-to-date educational programs for sustainability at all three levels of educational process.
\end{abstract}

\section{Introduction}

Modern world has been a global market for quite a long time already. Education is also a product sold around. Potential clients have their own criteria to define the university they would like to study at, but a lot of them study international rankings to be sure in their choice. Project for improving international competitiveness of Russian Institutions of Higher Education with a nominal title "5/100" was initiated in 2013 within the framework of the President's order № 599 "On the measures of realization of state policy in the sphere of education and science". One of the goals is the presence of at least five Russian Universities in top-100 world Universities-leaders to the year 2020 according to International rankings ARWU, QS, THE. There is a number of factors influencing the position of the University in the ranking but for educators the main pride of the University is highly qualified graduates. Two issues of high qualification are under constant analysis first being an educator's concern how to train a good specialist and the second is what specialist are on demand for the global development.

\section{${ }^{a}$ Corresponding author : daneykin@tpu.ru}




\section{Authors artwork}

One of the newest trends in engineering education is the concept of sustainable development. The idea of sustainable development originates from numerous environmental movements in earlier decades and was defined in 1987 by the World Commission on Environment and Development (Brundtland Commission 1987) as: "Development that meets the needs of the present without compromising the ability of future generations to meet their own needs" [1]. To support the concept and implement it into life it is necessary to train specialists able to promote sustainable development that inevitably leads to the necessity to develop educational programs embracing newest approaches considering upto-date conditions and requirements. The term "Education for sustainable development is used by the United Nations Organization and all international community. As a recognition of the importance of education for sustainable development General assembly of UNO declared the years 2005-2014 as a decade of education for sustainable development with the aim to transfer to sustainable development through all forms of education, social consciousness and highlighting the important role of education and learning. Education for sustainable development implies a synergy of disciplines targeted at research and solution of global problems in resource efficiency, satisfaction of human needs while keeping the environment so that these needs will be satisfied not only for the present but also for future generations. There have been quite a lot of work done by educators around the world to analyze the insight of engineering educational programs for sustainable development and find approaches for training engineers ready to promote the concept of sustainable development. Some colleagues find it necessary to cooperate tightly with industries to be perfectly aware of their need and structure educational programs accordingly [2]. American researches found their way adapting 12 principles of Green Engineering that can be the basis for educational programs for sustainable development [3] and analyzing how comfortably they are incorporated into the education for sustainability. They also indicate the problem common for Universities around the world - the virtual absence of comprehensive educational programs preparing specialists for sustainable development at all three levels of educational process: Bachelor's, Master's and $\mathrm{PhD}$ levels.

In addition, the following elements can be considered as essential when developing educational programs.

- Opportunity for fundamental research to receive new knowledge on the process of transition to the sustainable development of modern society.

- Opportunity for applied research for the creation and promotion of the culture for sustainable development, global system thinking in the interests of sustainable development.

- Development of regional programs for sustainable development taking into account local peculiarities of environment, social and economic factors, cultural aspects, industry, population etc.

- Detection of the systems of indicators of sustainable development, analysis of the data and opportunity to track the progress on the path to sustainable development.

- Problems and prospects of transition to sustainable development.

We analyzed what educational programs exist on the example of leading Universities according to ranking Times Higher Education-QS 2013-2014 [4] (Table 1).

Table 1. Educational programs on the example of leading Universities.

\begin{tabular}{l|l}
$\begin{array}{l}\text { Washington University } \\
\text { in St. Louis }\end{array}$ & $\begin{array}{l}\text { The University positions itself as a national leader in the sphere of sustainable } \\
\text { development. It offers Bachelor's educational program providing interdisciplinary } \\
\text { approach to understanding complex ecological, economic and social problems. } \\
\text { Students look inside sustainable life style from different points of view including } \\
\text { scientific, political, economic, social and philosophic. Educational program } \\
\text { embraces three main directions in sustainable development: ecological, business } \\
\text { strategies for sustainable development and design of sustainable spaces. Program } \\
\text { highlights development from local to global and considers the quality of life of a } \\
\text { person, efficiency of institutions and safety of the planet. }\end{array}$
\end{tabular}




\begin{tabular}{|c|c|}
\hline $\begin{array}{l}\text { The University of Hong } \\
\text { Kong }\end{array}$ & $\begin{array}{l}\text { The University provides several courses in sustainable development. One of them } \\
\text { encompasses general issues of sustainable development; the second is devoted to } \\
\text { "smart" architecture. Students of the third course explore projects of the future and } \\
\text { research interactions between environment and social contexts. One more course is } \\
\text { mainly concerned with energy issues with some aspects of climate change. }\end{array}$ \\
\hline Peking University & $\begin{array}{l}\text { The University has an experience of conducting summer seminar "Global } \\
\text { sustainable development". The seminar involves discussing sustainable } \\
\text { development in technical, social, economic and ethical aspects. Various issues are } \\
\text { under discussion, such as climate change, human health, clean water, energy, } \\
\text { biodiversity, ecosystems, poverty, human resources, safety, globalization and } \\
\text { economy. }\end{array}$ \\
\hline Boston University & $\begin{array}{l}\text { The University offers certificate program in "Sustainable development in energy" } \\
\text { which includes courses in business studies, economy, politics and engineering } \\
\text { disciplines. }\end{array}$ \\
\hline Princeton University & $\begin{array}{l}\text { The Program in Sustainable Energy is designed for Princeton undergraduate } \\
\text { students who are interested in pursuing careers or graduate education in the area of } \\
\text { Sustainable Energy Science and Technology. The program includes courses in } \\
\text { energy resources, technologies and their influence on climate and environment, } \\
\text { development of innovative energy systems, understanding of global climate. In } \\
\text { addition, it puts accent on joint research in the sphere of renewable energy sources } \\
\text { and alternative fuels. }\end{array}$ \\
\hline Cambridge University & $\begin{array}{l}\text { The Prince of Wales's Business \& Sustainability Programme has been developing } \\
\text { for more than twenty years and serves a strategic forum for top leaders for the } \\
\text { study of innovative and pragmatic approaches for sustainable development. }\end{array}$ \\
\hline $\begin{array}{l}\text { Imperial College of } \\
\text { London }\end{array}$ & $\begin{array}{l}\text { Master's program in "Sustainable development Futures" is aimed at the } \\
\text { development of new generation of leaders in energy sector and designed mostly } \\
\text { for the students with knowledge of Physics. The course gives fundamental } \\
\text { knowledge in global issues of energy industry and sustainable energy technologies. }\end{array}$ \\
\hline University of California & $\begin{array}{l}\text { The University offers the program "Leaders in Sustainable Development". } \\
\text { Economic, ecological and social factors are considered as key elements of } \\
\text { sustainable development. One of the advantages of the program is facilitating } \\
\text { students' cooperation with different specialists that can help looking more widely } \\
\text { at the problems of sustainable development. }\end{array}$ \\
\hline $\begin{array}{lr}\text { Johns } & \text { Hopkins } \\
\text { University, } \quad \text { Whiting } \\
\text { School of Engineering }\end{array}$ & $\begin{array}{l}\text { Minor educational program "Engineering for Sustainable development" is } \\
\text { concerned with poverty, social inequality. The specialist graduating this program } \\
\text { will cooperate with a wide circle of organizations and subjects including national } \\
\text { and local authorities, non-governmental organizations and local communities. } \\
\text { Engineering program students learn approaches to data gathering in various } \\
\text { conditions. }\end{array}$ \\
\hline $\begin{array}{ll}\text { University } & \text { of } \\
\text { Wisconsin-Madison }\end{array}$ & $\begin{array}{l}\text { Master's educational program "Sustainable development of Engineering Systems" } \\
\text { prepares for work with complex systems and their influence on the quality of } \\
\text { water, earth, air, energy, economy and society. }\end{array}$ \\
\hline
\end{tabular}

We can see from the table that mostly educational programs for sustainable development focus on social, energy and environmental factors. Some programs imply global approach to the issues of sustainability, while others can concentrate on local needs, like smart architecture for Hong Kong. Even leading Universities do not offer educational programs in all three levels: Bachelor's, Master's and Postgraduate's degrees. So it necessary to find approach that can be used for developing complex engineering educational programs.

Many universities around the world use the CDIO approach (Conceive, Design, Implement, Operate) to update their Bachelor's (BEng) programs to prepare graduates to more complex engineering activities at all stages of the life cycle of technical objects, processes and systems [5]. This approach is widely used, as it is consistent with the requirements of international standards (IAE Graduate Attributes and Professional Competences) to the engineering HEI's graduate learning outcomes and competences of professional engineers (www.ieagreements.org/IEA-Grad-Attr-ProfCompetencies.pdf). The CDIO approach allows the design and implementation of BEng programs as a 
basic engineering education in accordance with the criteria for accreditation of engineering programs in the countries - signatories of the Washington Accord, including the accreditation criteria of the Association for Engineering Education of Russia (AEER) [6]. In some Universities "CDIO concept was regarded as a new model for engineering education whose aims were to develop students' ability of engineering application to solve their employment problems efficiently" [7].

Today, more than 100 universities from 25 countries joined the World initiative CDIO, 10 of them - Russian, such as Skoltech (Moscow), TPU (Tomsk), URFA (Ekaterinburg), TUSUR (Tomsk) MAMI (Moscow) and many others.

Some features of these universities:

- 9 of them are simultaneously present in the QS rankings, THE, ARWU, (including 5 TOP-100) 45 simultaneously in 2 rankings of 3;

- 44 are in the TOP-500 QS rankings, TPU takes 485 place;

- 33 are in the TOP-300 rating in THE, TPU takes 251-300 place;

- 10 are in the TOP-100 rating in ARWU.

In 2013, «CDIO RUSSIA» academy was founded to promote the project-oriented approach to education and facilitate educational process in accordance with the standards of the World CDIO Initiative.

In October 2011, TPU joined the worldwide CDIO concept, becoming the first Russian university that adopted the initiative of leading universities in the modernization of engineering education. A series of workshops were held to explain the basic principles of the concept of modernization of engineering education, including those at international level (The Royal Institute of Technology, November 2011).

There are 12 Standards offered by CDIO Approach [8]:

STANDARD 1: The Context

STANDARD 2: Learning Outcomes

STANDARD 3: Integrated Curriculum

STANDARD 4: Introduction to Engineering

STANDARD 5: Design-Implement Experiences

STANDARD 6: Engineering Workspaces

STANDARD 7: Integrated Learning Experiences

STANDARD 8: Active Learning

STANDARD 9: Enhancement of Faculty Competence

STANDARD 10: Enhancement of Faculty Teaching Competence

STANDARD 11: Learning Assessment

STANDARD 12: Program Evaluation

These Standards indicate a clear direction for the development. In December 2011, TPU authorities approved the list of "pilot" educational programs for modernization in accordance with the CDIO standards: Technological machinery and equipment, Chemical Technology and Power and Electrical Engineering. All actions for updating "pilot" programs were grouped into three main areas.

Comprehensive modernization of educational programs begins with the definition of the status based on evaluation of compliance of general educational programs (GEP) with CDIO Standards. Concept, objectives, learning outcomes, content, and technology of implementation of GEP should be adjusted according to the nature and content of future engineering activity of the graduates. Developers of educational programs expect various learning outcomes including fundamental knowledge and acquisition of practical skills, formation of personal and interpersonal qualities of graduates and developing their responsibility for economic, social and environmental impact of engineering activity.

Organization of workspace implies a gradual and systematic improvement of logistical and laboratory facilities of the University, as well as the creation of "workspace islands" for practiceoriented training, for team and independent activity of students. 
The development of competencies of teachers involves improving their skills in the field of engineering activities (training at the enterprise sector) and in the area of problem-oriented and project-organized learning technologies (seminars and training in the CDIO-participating universities).

Designing educational programs using the developed Standards can guarantee comprehension and high quality of the programs as they embrace different aspects and look deep inside the content, pedagogical, and methodological sense. Standards cover content aspects and results, requirements to qualification of both students and professors, touch upon the quality of working environment, and involve teaching methods.

The content-related part of educational programs can be designed using CDIO Syllabus. If we analyze the Syllabus [9], we can see how it can be adopted to the programs on Sustainability.

The first part of the Syllabus is devoted to Disciplinary knowledge and reasoning, which includes knowledge of underlying Mathematics and Sciences (with Mathematics, statistics, Chemistry and Biology inside), core engineering fundamental knowledge and advanced engineering fundamental knowledge, methods and tools. As we can see this part is highly compatible to the idea of education for sustainability. The specialist in sustainability, especially looking at environmental, climate and energy aspects is supposed to acquire definite scientific background.

The second part of the Syllabus embraces personal and professional skills and attributes. Uncovering the inside we can see the following items: analytic reasoning and problem solving, experimentation, investigation and knowledge discovery, system thinking, attitude thoughts and learning, ethics, equity and other responsibilities. All these aspects are on high demand for the specialist in sustainability as providing the specialist with skills both useful and necessary. It might be topical to decide to what degree these aspects should be developed at all three levels of education [10, 11]. For example developing responsibility is crucial at all three levels as each specialist ought to be responsible for the part of duties they undertake. As for analytical reasoning and investigation, they might be on more advanced levels for Master's and Postgraduate's degree students.

Third part of the Syllabus includes Interpersonal skills: teamwork and communication. Some of the programs of leading Universities listed above stress the necessity of cooperation of a specialist in sustainability with other specialists and developing teamwork and communication skills will prepare students to more fruitful collaboration in the future with the colleagues and organizations.

The forth part includes conceiving, designing, implementing and operating systems in the enterprise, societal and environmental context - the innovation process (with external, societal and environmental context, enterprise and business context, conceiving, system engineering and management, designing, implementing and operating inside). The compliance of this part of the Syllabus with the skills and knowledge of a specialist in sustainable development is obvious. Although, it might be disputable in what volume these knowledge should be given to specialist at all three levels of education. It seems reasonable that conceiving is more a prerogative of postgraduate student while operating will be more a function of a Bachelor.

\section{Conclusion}

The concept of sustainable development is one of the newest trends in engineering education. To support the concept and implement it into life it is necessary to train specialists able to promote sustainable development that inevitably leads to the necessity to develop educational programs embracing newest approaches considering up-to-date conditions and requirements.

Education for sustainable development implies a synergy of disciplines targeted at research and solution of global problems in resource efficiency, satisfaction of human needs while keeping the environment so that these needs will be satisfied not only for the present but also for future generations.

One of the common problems for Universities around the world is the virtual absence of comprehensive educational programs preparing specialists for sustainable development at all three levels of educational process: Bachelor's, Master's and PhD levels. 


\section{MATEC Web of Conferences}

Existing programs can be clearly divided into the following types: Bachelor's programs, Master's programs, certificate courses, summer seminars. There are programs that cover quite many aspects of sustainable development including technical, scientific, economic and political issue, while others have a narrower sphere (for example "smart" architecture). Nevertheless, it is still a necessity to develop a comprehensive approach to the design of educational programs at all three levels of education: Bachelor's, Master's and Postgraduate degrees.

Many universities around the world use the CDIO approach (Conceive, Design, Implement, Operate) to update their Bachelor's (BEng) programs to prepare graduates to more complex engineering activities at all stages of the life cycle of technical objects, processes and systems and this Approach, including CDIO Syllabus, might be successfully applied to develop up-to-date educational programs for sustainability at all three levels of educational process with some consideration of the extent to what different knowledge and skills should be given and developed at each stage of educational process. CDIO Standards may serve as a guarantee for the high quality of educational programs.

\section{References}

1. Official site of Global Issues Organization. URL: http://www.globalissues.org/article/408/sustainable-development-introduction (2016)

2. G. Kruss, et al. Int. J of Edu. Dev. 43, 22 (2015)

3. C. Murphy, et al. Environ. Sci. Technol. 43, 5558 (2009)

4. Yu. Daneykin, N. Daneikina, Priv. Sci. Bul. 41, 41 (2015)

5. A. Chuchalin, Proceedings 8th International CDIO Conference (Queensland University of Technology, Brisbane, 2012)

6. A. Chuchalin, M. Tayurskaya, J. Malmqvist, Eur. J. of Eng. Edu. (to be published)

7. J. Bai, et al. Procedia - Social and Behavioral Sciences 93, 381 (2013)

8. CDIO organization. URL: http://www.cdio.org/implementing-cdio/standards/12-cdio-standards (2016)

9. CDIO organization. URL: http://www.cdio.org/benefits-cdio/cdio-syllabus/cdio-syllabus-topicalform (2016)

10. A. Chuchalin, N. Daneikina, CDIO Proceedings (to be published)

11. V. Ivanova, K. Mertins, Mat. Web of Conf. 37, 01025 